\title{
Prognostic role of tumor-infiltrating Iymphocytes in gastric cancer: a meta-analysis
}

\author{
Xiao Zheng ${ }^{1,2,3, *}$, Xing Song ${ }^{4, *}$, Yingjie Shao ${ }^{4}$, Bin $X^{1,2,3}$, Lujun Chen ${ }^{1,2,3}$, Qi Zhou ${ }^{5}$, \\ Wenwei Hu${ }^{5}$, Dachuan Zhang ${ }^{6}$, Changping Wu ${ }^{1,2,5}$, Min Tao ${ }^{3}$, Yibei Zhu ${ }^{3}$ and Jingting \\ Jiang ${ }^{1,2,3}$ \\ ${ }^{1}$ Department of Tumor Biological Treatment, The Third Affiliated Hospital of Soochow University, Changzhou 213003, People's \\ Republic of China \\ ${ }^{2}$ Jiangsu Engineering Research Center for Tumor Immunotherapy, Changzhou 213003, People's Republic of China \\ ${ }^{3}$ Institute of Cell Therapy, Soochow University, Changzhou 213003, People's Republic of China \\ ${ }^{4}$ Department of Radiation Oncology, The Third Affiliated Hospital of Soochow University, Changzhou 213003, People's \\ Republic of China \\ ${ }^{5}$ Department of Oncology, The Third Affiliated Hospital of Soochow University, Changzhou 213003, People's Republic of China \\ ${ }^{6}$ Department of Pathology, The Third Affiliated Hospital of Soochow University, Changzhou 213003, People's Republic of China \\ *These authors have contributed equally to this work \\ Correspondence to: Jingting Jiang, email: jiangjingting@suda.edu.cn \\ Keywords: TILs, prognosis, gastric cancer, biomarker, meta-analysis \\ Received: February 28, $2017 \quad$ Accepted: April 26, $2017 \quad$ Published: May 22, 2017 \\ Copyright: Zheng et al. This is an open-access article distributed under the terms of the Creative Commons Attribution License 3.0 \\ (CC BY 3.0), which permits unrestricted use, distribution, and reproduction in any medium, provided the original author and source \\ are credited.
}

\section{ABSTRACT}

Background: In patients with gastric cancer, the prognostic value of tumorinfiltrating lymphocytes (TILs) is still controversial. A meta-analysis was performed to evaluate the prognostic value of TILs in gastric cancer.

Materials and methods: We identify studies from PubMed, Embase and the Cochrane Library to assess the prognostic effect of TILs in patients with gastric cancer. Fixed-effects models or random-effects models were used estimate the pooled hazard ratios (HRs) for overall survival (OS) and disease-free survival (DFS), which depend on the heterogeneity.

Results: A total of 31 observational studies including 4,185 patients were enrolled. For TILs subsets, the amount of $\mathrm{CD}^{+}, \mathrm{FOXP3}^{+}, \mathrm{CD}^{+}, \mathrm{CD}^{+} 7^{+}, \mathrm{CD2O}^{+}, \mathrm{CD} 4 \mathrm{RO}^{+}, \mathrm{Granzyme}$ $\mathrm{B}^{+}$and $\mathrm{T}$-bet ${ }^{+}$lymphocytes was significantly associated with improved survival $(P<$ 0.05); moreover, the amount of CD3+ TILs in intra-tumoral compartment (IT) was the most significant prognostic marker (pooled HR $=0.52 ; 95 \% \mathrm{CI}=0.43-0.63 ; P<0.001$ ). However, CD4+ ${ }^{+}$TILs was not statistically associated with patients' survival. FOXP3+ TILs showed bidirectional prognostic roles which had positive effect in IT (pooled $H R=1.57 ; 95 \% C I=1.04-2.37 ; P=0.033$ ) and negative effect in extra-tumoral compartment (ET) (pooled HR $=0.76 ; 95 \% \mathrm{CI}=0.60-0.96 ; P=0.022$ ).

Conclusions: This meta-analysis suggests that some TIL subsets could serve as prognostic biomarkers in gastric cancer. High-quality randomized controlled trials are needed to decide if these TILs could serve as targets for immunotherapy in gastric cancer.

\section{INTRODUCTION}

Gastric cancer has become a big health issue worldwide due to high morbidity and mortality [1].
Although the incidence and mortality of gastric cancer has been decreasing over the past decade, it is still the third cause of cancer death in men and the second in women in China [2]. Besides early diagnosis, appropriate treatment 
plans identified from the prediction of patients' outcomes also contribute to successful treatment of gastric cancer. Therefore, further investigation is needed to identify newer tumor biomarkers with higher specificity and sensitivity in gastric cancer to determine the optimal therapeutic strategies and predict the prognosis of gastric cancers.

Tumor-infiltrating lymphocytes (TILs) are a heterogeneous group containing tumor-infiltrating $\mathrm{T}$ cells, B cells, and natural killer (NK) cells [3]. There are many specific antigens such as CD3, CD4, CD8, FOXP3, CD20, CD57 in the cell membrane of TILs. Usually, different cell surface antigens bind to specific type of lymphocytes. For example, CD3, CD4, CD8, FOXP3 bind to T cells; CD20 binds to B cells; and CD57 binds to NK cells. Thus, TILs play a bidirectional regulation roles in the tumor-associated immune responses: It can not only inhibit tumor growth by suppressing their outgrowth or destroying cancer cells, but also contribute to tumor progression either by creating a tumor microenvironment that stimulate tumor outgrowth or by selectively protecting tumor cell survival in an immunocompetent host [4].

TILs might be a prognostic biomarker in gastric cancer. Many studies have verified TILs for use in prognostic prediction besides their crucial role in tumorassociated immune responses in gastric cancer [5-8]. Lee et al. found that high infiltration of $\mathrm{CD}^{+} \mathrm{T}$ cells was associated with better outcome [5], whereas no correlation between the infiltration of $\mathrm{CD} 8^{+} \mathrm{T}$ cells and clinical outcome was found in Hass et al. study [6]. Zhou et al. revealed that patients with high density of $\mathrm{FOXP}^{+} \mathrm{T}$ cell had worse overall survival (OS) [7], but Kim et al. reported the opposite results [8]. Therefore, the prognostic role of TILs in gastric cancer remains controversial. It is also unclear whether the associations between the density of TILs and prognosis vary depending on survival-associated factors such as the endpoints and anatomical location. In view of the above-mentioned facts, to assess the prognostic effect of TILs in gastric cancer, we performed this meta-analysis.

\section{RESULTS}

\section{Study characteristics}

A total of 288 references were initially collected in our study. Among them, 43 articles reported the association between the density of TILs and patients' outcomes in gastric cancer. After further screening, 12 articles were excluded (one studying the same population, three lacking enough sample size, and eight without some useful data). Finally, we incorporated 31 articles including 4,185 patients from Italy, Japan, Germany, China, Korea, Turkey and France into this meta-analysis (Figure 1) [5-35].

The main characteristics of studies were showed in Table 1. Among these, only five articles, including 875 patients with gastric cancer, reported the prognostic value of generalized TILs [9, 10, 13, 15, 29], and others focused on specific TIL subsets. The prognostic role of TILs in intra-tumoral compartment (IT) and extra-tumoral compartment (ET) were evaluated in 31 and 5 articles, respectively. 20 articles have large sample size $(\geq 100)$. The details of tumor stage were provided in 21 articles, and the categorizations were various. Follow-up time was available in 27 articles, and the number of articles with median follow-up of more than 60 months was 11 . The cut-off values contained mean value $(n=5)$, median value $(\mathrm{n}=17)$, and others. Specific TIL subsets and generalized TILs were detected by means of immunohistochemistry (IHC) staining and Hematoxylin-eosin (HE) staining,

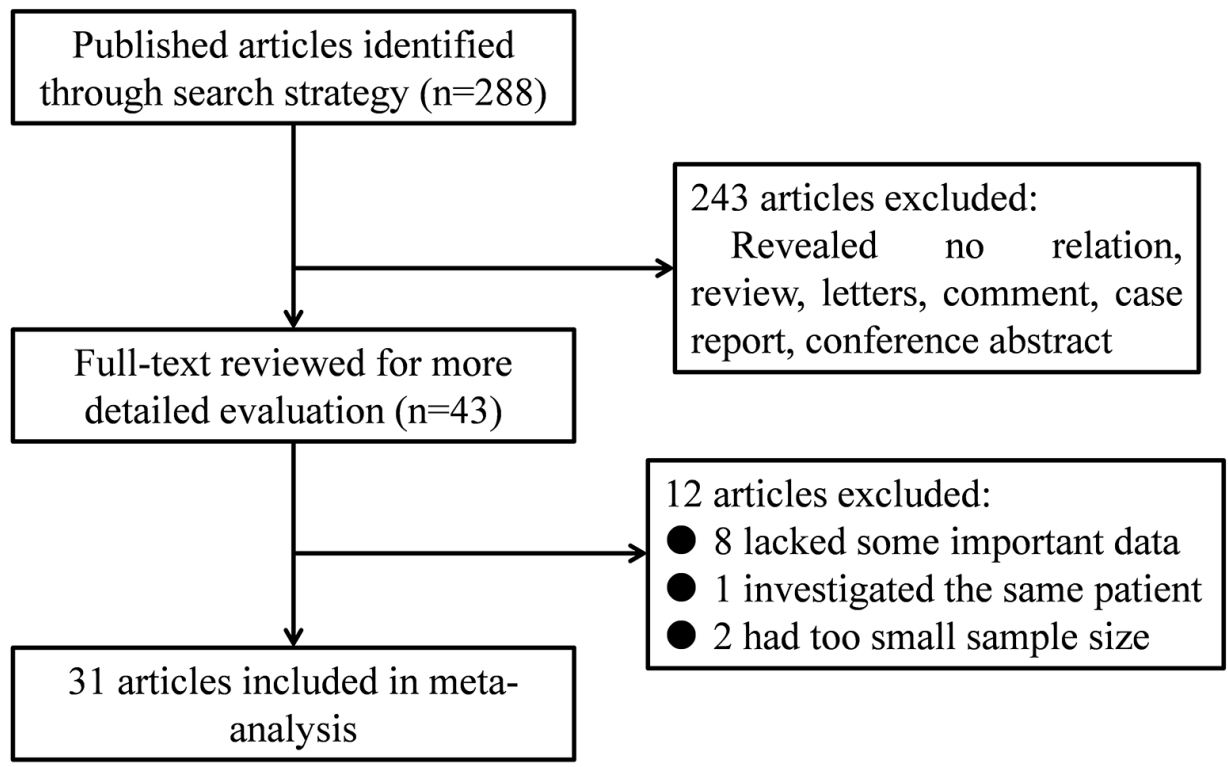

Figure 1: Flow diagram of the study selection process. 
Table 1: Main characteristics of all studies included in the meta-analysis

\begin{tabular}{|c|c|c|c|c|c|c|c|c|c|c|}
\hline Study & Subset & Location & Country & $\begin{array}{c}\text { Case } \\
\text { number }\end{array}$ & Tumor stage & $\begin{array}{l}\text { Follow-up } \\
\text { (months) }\end{array}$ & $\begin{array}{c}\text { Detected } \\
\text { method }\end{array}$ & Cut-off value & $\begin{array}{c}\text { HRs } \\
\text { provided } \\
\text { from }\end{array}$ & Outcome \\
\hline \multirow[t]{2}{*}{ Chiaravalli 2005 [11] } & $\mathrm{CD}^{+}$ & IT & Italy & 96 & $27 / 31 / 30 / 8$ & $64.3(0-238)$ & $\mathrm{IHC}$ & median & $\mathrm{sc}$ & OS \\
\hline & $\mathrm{CD}^{+}$ & IT & Italy & 71 & NR & $64.3(0-238)$ & $\mathrm{IHC}$ & median & $\mathrm{sc}$ & OS \\
\hline \multirow[t]{2}{*}{ Ishigami 1999 [29] } & $\mathrm{CD} 57^{+}$ & IT & Japan & 146 & $54 / 26 / 27 / 39$ & 87 & $\mathrm{IHC}$ & $>25$ cells $/ \mathrm{HPF}$ & report & OS \\
\hline & TILs & IT & Japan & 146 & $54 / 26 / 27 / 39$ & 87 & $\mathrm{HE}$ & $>150$ cells/HPF & report & OS \\
\hline Ohno 2002 [27] & $\mathrm{CD}^{+}$ & IT & Japan & 84 & I-II31/III-IV53 & $38.3(2.9-109)$ & $\mathrm{IHC}$ & median & report & DFS \\
\hline Gochi 2001 [9] & TILs & IT & Japan & 159 & NR & $>120$ & $\mathrm{HE}$ & $\begin{array}{l}\text { moderate or } \\
\text { marked }\end{array}$ & report & OS \\
\hline \multirow[t]{5}{*}{ Haas 2009 [6] } & $\mathrm{CD}^{+}$ & $\begin{array}{c}\text { Primary/ } \\
\text { Metastasis/ Normal }\end{array}$ & Germany & 52 & $20 / 19 / 10 / 3$ & $71.2(54.7-57.8)$ & $\mathrm{IHC}$ & mean & report & OS \\
\hline & $\mathrm{CD}^{+}$ & $\begin{array}{c}\text { Primary/ } \\
\text { Metastasis/ Normal }\end{array}$ & Germany & 52 & $20 / 19 / 10 / 3$ & $71.2(54.7-57.8)$ & $\mathrm{IHC}$ & mean & report & OS \\
\hline & $\mathrm{CD} 20^{+}$ & $\begin{array}{l}\text { Primary/ } \\
\text { Metastasis }\end{array}$ & Germany & 52 & $20 / 19 / 10 / 3$ & $71.2(54.7-57.8)$ & $\mathrm{IHC}$ & mean & report & OS \\
\hline & $\mathrm{FOXP}^{+}$ & $\begin{array}{c}\text { Primary/ } \\
\text { Metastasis/ Normal }\end{array}$ & Germany & 52 & $20 / 19 / 10 / 3$ & $71.2(54.7-57.8)$ & $\mathrm{IHC}$ & mean & report & OS \\
\hline & Granzyme B & $\begin{array}{c}\text { Primary/ } \\
\text { Metastasis/ Normal }\end{array}$ & Germany & 52 & $20 / 19 / 10 / 3$ & $71.2(54.7-57.8)$ & $\mathrm{IHC}$ & mean & report & OS \\
\hline \multirow[t]{2}{*}{ Dong 2013 [19] } & $\mathrm{CD}^{+}$ & IT & China & 100 & $4 / 55 / 38 / 3$ & $36.5(2-88)$ & $\mathrm{IHC}$ & median & report & OS/DFS \\
\hline & $\mathrm{CD} 20^{+}$ & IT & China & 100 & $4 / 55 / 38 / 3$ & $36.5(2-88)$ & $\mathrm{IHC}$ & median & report & OS/DFS \\
\hline Ishigami 2001 [28] & $\mathrm{CD}^{+}$ & IT & Japan & 185 & $86 / 36 / 34 / 27$ & $>60$ & $\mathrm{IHC}$ & $66 \%$ & $\mathrm{sc}$ & OS \\
\hline \multirow[t]{2}{*}{ Kijima 2003 [34] } & $\mathrm{CD}^{+}$ & IT & Japan & 66 & NR & $30(1-176)$ & $\mathrm{IHC}$ & $\geq 50$ cells $/ \mathrm{HPF}$ & report & OS \\
\hline & $\mathrm{CD} 57^{+}$ & IT & Japan & 64 & NR & $30(1-176)$ & $\mathrm{IHC}$ & $\geq 25$ cells $/ \mathrm{HPF}$ & report & OS \\
\hline Ishigami 2000 [30] & $\mathrm{CD} 57^{+}$ & IT & Japan & 169 & NR & $63(13-122)$ & $\mathrm{IHC}$ & $\geq 25$ cells $/ \mathrm{HPF}$ & $\mathrm{sc}$ & OS \\
\hline Mizukami 2007 [33] & $\mathrm{FOXP}^{+}$ & IT & Japan & 80 & $42 / 12 / 15 / 11$ & 87.7 & $\mathrm{IHC}$ & median & report & OS \\
\hline \multirow[t]{3}{*}{ Lee 2008 [5] } & $\mathrm{CD}^{+}$ & IT & Korea & 220 & $67 / 53 / 55 / 45$ & $64.4(1-108)$ & $\mathrm{IHC}$ & mean & report & OS \\
\hline & $\mathrm{CD}^{+}$ & IT & Korea & 220 & $67 / 53 / 55 / 45$ & $64.4(1-108)$ & $\mathrm{IHC}$ & mean & report & OS \\
\hline & $\mathrm{CD} 4 \mathrm{RO}^{+}$ & IT & Korea & 220 & $67 / 53 / 55 / 45$ & $64.4(1-108)$ & $\mathrm{IHC}$ & mean & report & OS \\
\hline Perronea 2008 [16] & $\mathrm{FOXP}^{+}$ & IT & Italy & 110 & II46/III46 & $>36$ & $\mathrm{IHC}$ & median & report & OS/DFS \\
\hline \multirow[t]{3}{*}{ Shen 2010 [35] } & $\mathrm{CD}^{+}$ & $\begin{array}{l}\text { IT / Peri-tumor/ } \\
\text { TDLN }\end{array}$ & China & 133 & I-II66/III-IV67 & $43(36-104)$ & $\mathrm{IHC}$ & median & report & OS \\
\hline & $\mathrm{CD}^{+}$ & $\begin{array}{l}\text { IT / Peri-tumor/ } \\
\text { TDLN }\end{array}$ & China & 133 & I-II66/III-IV67 & $43(36-104)$ & $\mathrm{IHC}$ & median & report & OS \\
\hline & $\mathrm{FOXP}^{+}$ & $\begin{array}{l}\text { IT / Peri-tumor/ } \\
\text { TDLN }\end{array}$ & China & 133 & I-II66/III-IV67 & $43(36-104)$ & $\mathrm{IHC}$ & median & report & OS \\
\hline Wang 2011 [14] & $\mathrm{FOXP}^{+}$ & $\begin{array}{c}\text { IT / Peri-tumor / } \\
\text { Normal }\end{array}$ & China & 107 & $33 / 21 / 21 / 32$ & $62(2-120)$ & $\mathrm{IHC}$ & median & report & OS \\
\hline Lu 2011 [32] & $\mathrm{FOXP}^{+}$ & IT & China & 60 & NR & NR & $\mathrm{IHC}$ & median & $\mathrm{sc}$ & OS \\
\hline \multirow[t]{5}{*}{ Kim 2011 [17] } & $\mathrm{CD}^{+}$ & IT & China & 180 & I-II91/III89 & median 45 & $\mathrm{IHC}$ & median & report & OS/DFS \\
\hline & $\mathrm{CD}^{+}$ & IT & China & 180 & I-II91/III89 & median 45 & $\mathrm{IHC}$ & median & report & OS/DFS \\
\hline & $\mathrm{CD}^{+}$ & IT & China & 180 & I-II91/III89 & median 45 & $\mathrm{IHC}$ & median & report & OS/DFS \\
\hline & $\mathrm{FOXP}^{+}$ & IT & China & 180 & I-II91/III89 & median 45 & $\mathrm{IHC}$ & median & report & OS/DFS \\
\hline & Granzyme $\mathrm{B}^{+}$ & IT & China & 180 & I-II91/III89 & median 45 & $\mathrm{IHC}$ & median & report & OS/DFS \\
\hline Ishigami 2012 [31] & $\mathrm{FOXP}^{+}$ & IT & Japan & 141 & NR & NR & $\mathrm{IHC}$ & mean & sc & OS \\
\hline Chen 2012 [24] & T-bet ${ }^{+}$ & IT & China & 152 & $10 / 31 / 93 / 18$ & NR & $\mathrm{IHC}$ & NR & report & OS/DFS \\
\hline Diricana 2013 [10] & TILs & IT & Turkey & 52 & NR & NR & $\mathrm{HE}$ & NR & $\mathrm{sc}$ & $\begin{array}{c}\text { OS } \\
\text { (Continue }\end{array}$ \\
\hline
\end{tabular}




\begin{tabular}{|c|c|c|c|c|c|c|c|c|c|c|}
\hline Study & Subset & Location & Country & $\begin{array}{c}\text { Case } \\
\text { number }\end{array}$ & Tumor stage & $\begin{array}{c}\text { Follow-up } \\
\text { (months) }\end{array}$ & $\begin{array}{c}\text { Detected } \\
\text { method }\end{array}$ & Cut-off value & $\begin{array}{c}\text { HRs } \\
\text { provided } \\
\text { from }\end{array}$ & Outcome \\
\hline \multirow[t]{2}{*}{ Kim 2013 [8] } & $\mathrm{CD}^{+}$ & IT & Korea & 99 & I-II60/III-IV39 & $59(1-96)$ & $\mathrm{IHC}$ & median & report & OS \\
\hline & $\mathrm{FOXP}^{+}$ & IT & Korea & 99 & I-II60/III-IV39 & $59(1-96)$ & $\mathrm{IHC}$ & median & report & OS \\
\hline Kang 2015 [13] & TILs & IT & Korea & 120 & $74 / 26 / 19 / 1$ & $22.2(2.1-50.8)$ & $\mathrm{HE}$ & median & report & DFS \\
\hline Giampieri 2015 [26] & $\mathrm{CD}^{+}$ & IT & Italy & 103 & NR & $>12$ & $\mathrm{IHC}$ & $\geq 50-60 \%$ & report & OS \\
\hline Dai 2016 [15] & TILs & IT & China & 398 & $\begin{array}{l}\text { I-II132/III- } \\
\text { IV262 }\end{array}$ & $61.2(12.2-79.9)$ & $\mathrm{HE}$ & NR & report & OS \\
\hline Chen 2011 [18] & $\mathrm{CD}^{+}$ & IT & China & 192 & $8 / 71 / 94 / 19$ & $61(0.3-81.6)$ & $\mathrm{IHC}$ & median & report & OS \\
\hline $\mathrm{Hu} 2014$ [25] & $\mathrm{FOXP}^{+}$ & IT & China & 56 & I-II16/III-IV40 & $19(1-52)$ & IHC & median & Repor-t & OS \\
\hline \multirow[t]{2}{*}{ Li 2015 [20] } & $\mathrm{CD}^{+}$ & IT & China & 192 & I-II48/III-IV144 & $19.5(1-54)$ & IHC & median & report & OS \\
\hline & $\mathrm{CD}^{+}$ & IT & China & 192 & I-II48/III-IV144 & $19.5(1-54)$ & $\mathrm{IHC}$ & median & report & OS \\
\hline \multirow[t]{4}{*}{ Hennequin 2015 [12] } & $\mathrm{CD} 20^{+}$ & IT & France & 82 & I-III & median 27 & $\mathrm{IHC}$ & median & report & DFS \\
\hline & $\mathrm{CD}^{+}$ & IT / Peri-tumor & France & 82 & I-III & median 27 & $\mathrm{IHC}$ & median & report & DFS \\
\hline & $\mathrm{FOXP}^{+}$ & IT / Peri-tumor & France & 82 & I-III & median 27 & $\mathrm{IHC}$ & median & report & DFS \\
\hline & T-bet ${ }^{+}$ & IT / Peri-tumor & France & 82 & I-III & median 27 & $\mathrm{IHC}$ & median & report & DFS \\
\hline \multirow[t]{5}{*}{ Liu 2015 [21] } & $\mathrm{CD}^{+}$ & IT / Peri-tumor & China & 166 & $23 / 41 / 80 / 22$ & median 65.8 & $\mathrm{IHC}$ & median & report & OS \\
\hline & $\mathrm{CD}^{+}{ }^{+}$ & IT / Peri-tumor & China & 166 & $23 / 41 / 80 / 22$ & median 65.8 & $\mathrm{IHC}$ & median & report & OS \\
\hline & $\mathrm{CD}^{+}$ & IT / Peri-tumor & China & 166 & $23 / 41 / 80 / 22$ & median 65.8 & $\mathrm{IHC}$ & median & report & OS \\
\hline & $\mathrm{CD} 57^{+}$ & IT / Peri-tumor & China & 166 & $23 / 41 / 80 / 23$ & median 65.9 & $\mathrm{IHC}$ & median & report & OS \\
\hline & $\mathrm{FOXP}^{+}$ & IT / Peri-tumor & China & 166 & $23 / 41 / 80 / 23$ & median 65.9 & $\mathrm{IHC}$ & median & report & OS \\
\hline Wakatsuki 2012 [22] & $\mathrm{CD} 45 \mathrm{RO}^{+}$ & IT & Japan & 74 & $16 / 25 / 15 / 18$ & NR & $\mathrm{IHC}$ & mean & $\mathrm{sc}$ & OS/DFS \\
\hline Zhou 2013 [7] & $\mathrm{FOXP}^{+}$ & IT & China & 133 & NR & $43(36-104)$ & $\mathrm{IHC}$ & mean & report & OS \\
\hline \multirow[t]{2}{*}{ Kim 2015 [23] } & $\mathrm{CD} 8^{+}$ & IT & Korea & 143 & NR & $70(2-111)$ & $\mathrm{IHC}$ & median & sc & DFS \\
\hline & $\mathrm{FOXP}^{+}$ & IT & Korea & 143 & NR & $70(2-111)$ & $\mathrm{IHC}$ & median & $\mathrm{sc}$ & DFS \\
\hline
\end{tabular}

TILs: tumor-infiltrating lymphocytes; IT: intra-tumoral compartment; IHC: immunohistochemistry; TDLN: tumor draining lymph node; HE: Hematoxylin-eosin; OS: overall survival; DFS: disease-free survival; HR: hazard ratio; NR: not report; SC: survival curve.

respectively. 23 studies reported the Hazard ratios (HRs) directly, but the other 8 studies only provided KaplanMeier Survival curves. The endpoints OS and diseasefree survival (DFS) were provided in 27 and 9 studies, respectively.

\section{Subgroup analysis}

Different TIL subsets have different functions in the process of anti-tumor immunoreaction response. Therefore, subgroup analyses based on TIL subsets were performed. Then, given that the function of TILs is associated with the distribution site, we further performed subgroup analyses based on the distribution site of TILs. Table 2 shows the major results of subgroup analyses.

\section{Generalized TILs}

Five articles focused on the clinical outcome of patients with high density of generalized TILs in IT [9, $10,13,15,29]$. Four of the articles evaluated OS $[9,10$,
$15,29]$, and the pooled $\mathrm{HR}$ was $0.55(95 \% \mathrm{CI}=0.35-0.86$; $P=0.009$ ) (Figure 2A). Only one of them evaluated DFS [13], and there was no statistical significance between high density of generalized TILs and DFS in gastric cancer $(P=0.63)$.

\section{$\mathrm{CD8}^{+} \mathrm{T}$ lymphocyte subset}

In total, 14 articles including 1,803 patients with gastric cancer researched the clinical outcome of patients with high density of CD8 ${ }^{+}$TILs $[5,6,8,11,12,17-21,23$, $27,34,35]$. Stratified by the endpoints, there were 11 of OS and 5 of DFS, respectively.

\section{OS}

Eleven articles focused on the OS of patients with high density of CD $8^{+}$TILs in IT $[5,6,8,11,17-21$, $34,35]$. The pooled analysis revealed that high density of infiltration of $\mathrm{CD} 8^{+} \mathrm{T}$ lymphocytes was statistically significant associated with better OS (pooled HR $=0.73$; 
Table 2: The pooled associations between TILs subsets and the prognosis of patients with gastric cancer

\begin{tabular}{|c|c|c|c|c|c|c|c|}
\hline \multirow[t]{2}{*}{ Subset/Outcome } & \multirow[t]{2}{*}{ Location } & \multirow{2}{*}{$\begin{array}{c}\text { Study } \\
\text { number }\end{array}$} & \multirow[t]{2}{*}{ Case number } & \multirow[t]{2}{*}{ HR (95\%CI)-model } & \multirow[t]{2}{*}{$P$ value } & \multicolumn{2}{|c|}{ Heterogenety } \\
\hline & & & & & & $I^{2}(\%)$ & $P$ \\
\hline \multicolumn{8}{|l|}{ Generalized TILs } \\
\hline OS & IT & 4 & 755 & $0.55(0.35-0.86)$ - random & 0.009 & 62.4 & 0.047 \\
\hline DFS & IT & 1 & 120 & $0.21(0.04-1.09)$ & 0.063 & & \\
\hline \multicolumn{8}{|l|}{$\mathrm{CD}^{+}$} \\
\hline \multirow[t]{2}{*}{ OS } & IT & 12 & 1523 & $0.73(0.61-0.87)-$ fixed & $<0.001$ & 0 & 0.622 \\
\hline & ET & 4 & 484 & $0.71(0.53-0.97)$ - fixed & 0.029 & 0 & 0.583 \\
\hline \multirow[t]{2}{*}{ DFS } & IT & 5 & 589 & $0.57(0.35-0.94)$ - random & 0.029 & 79.5 & 0.001 \\
\hline & ET & 1 & 84 & $0.98(0.50-2.00)$ & 0.950 & & \\
\hline \multicolumn{8}{|l|}{$\mathrm{FOXP}^{+}$} \\
\hline \multirow[t]{2}{*}{ OS } & IT & 12 & 1369 & $1.57(1.04-2.37)$ - random & 0.033 & 71.6 & $<0.001$ \\
\hline & ET & 6 & 698 & $0.76(0.60-0.96)-$ fixed & 0.022 & 0 & 0.519 \\
\hline \multirow[t]{2}{*}{ DFS } & IT & 4 & 516 & $1.09(0.64-1.86)$ - random & 0.756 & 73.8 & 0.010 \\
\hline & ET & 1 & 85 & $1.23(0.60-2.50)$ & 0.500 & & \\
\hline \multicolumn{8}{|l|}{$\mathrm{CD}^{+}$} \\
\hline \multirow[t]{2}{*}{ OS } & IT & 8 & 1054 & $0.52(0.43-0.63)-$ fixed & $<0.001$ & 18.6 & 0.283 \\
\hline & ET & 2 & 218 & $0.80(0.38-1.65)$ - random & 0.542 & 50.1 & 0.157 \\
\hline DFS & IT & 1 & 180 & $0.70(0.43-1.15)$ & 0.163 & & \\
\hline \multicolumn{8}{|l|}{$\mathrm{CD}^{+}$} \\
\hline \multirow[t]{2}{*}{ OS } & IT & 4 & 671 & $0.82(0.54-1.24)$ - random & 0.353 & 60.9 & 0.053 \\
\hline & ET & 3 & 432 & $0.95(0.57-1.57)$ - random & 0.829 & 57.7 & 0.094 \\
\hline DFS & IT & 1 & 180 & $0.71(0.41-1.24)$ & 0.225 & & \\
\hline \multicolumn{8}{|l|}{$\mathrm{CD}_{57^{+}}$} \\
\hline \multirow[t]{2}{*}{ OS } & IT & 4 & 545 & $0.89(0.85-0.94)$ - fixed & $<0.001$ & 29.1 & 0.237 \\
\hline & ET & 1 & 166 & $0.73(0.47-1.14)$ & 0.162 & & \\
\hline \multicolumn{8}{|l|}{$\mathrm{CD} 20^{+}$} \\
\hline OS & IT & 3 & 204 & $0.73(0.24-2.25)$ - random & 0.588 & 71.5 & 0.030 \\
\hline DFS & IT & 2 & 182 & $0.54(0.34-0.86)$ - fixed & 0.010 & 0 & 0.364 \\
\hline \multicolumn{8}{|l|}{$\mathrm{CD} 4 \mathrm{RO}^{+}$} \\
\hline OS & IT & 2 & 294 & $0.56(0.37-0.84)$ - fixed & 0.005 & 0 & 0.526 \\
\hline DFS & IT & 1 & 74 & $0.58(0.29-1.18)$ & 0.096 & & \\
\hline Granzyme $\mathrm{B}^{+}$ & IT & & & & & & \\
\hline \multirow[t]{2}{*}{ OS } & IT & 3 & 284 & $0.82(0.52-1.28)-$ fixed & 0.376 & 0 & 0.975 \\
\hline & ET & 1 & 52 & $0.35(0.12-0.99)$ & 0.050 & & \\
\hline DFS & IT & 1 & 180 & $0.99(0.98-1.01)$ & 0.319 & & \\
\hline
\end{tabular}




\begin{tabular}{cccccccc}
\hline Subset/Outcome & Location & $\begin{array}{c}\text { Study } \\
\text { number }\end{array}$ & Case number & HR (95\%CI)-model & $\boldsymbol{P}$ value & Heterogenety \\
\hline T-bet $^{+}$ & & & & & $\boldsymbol{I}^{\mathbf{2}} \mathbf{( \% )}$ & $\boldsymbol{P}$ \\
OS & IT & & & & & \\
DFS & IT & 1 & 152 & $0.55(0.30-0.99)$ & 0.047 & & 0.833 \\
& IT & 2 & 235 & $0.54(0.34-0.87)$ & 0.012 & 0 & \\
\hline
\end{tabular}

OS: overall survival; DFS: disease-free survival; HR: hazard ratio; CI: confidence interval; IT: intra-tumoral compartment; ET: extra-tumoral compartment.

95\% CI $=0.61-0.87 ; P<0.001$ ) (Figure 2B). Subgroup analysis showed that patients with high infiltration of $\mathrm{CD} 8^{+} \mathrm{T}$ lymphocytes had better OS in the groups with large sample size $(\geq 100$; pooled $\mathrm{HR}=0.73,95 \%$ $\mathrm{CI}=0.60-0.88 ; P=0.001$ ), Asian patients (pooled HR $=0.72,95 \% \mathrm{CI}=0.60-0.87 ; P=0.001)$, and median cutoff values (pooled $\mathrm{HR}=0.73,95 \% \mathrm{CI}=0.60-0.89 ; P=$ $0.002)$. However, other subgroups showed no statistical significance (Table 3). We further performed a sensitivity analysis which demonstrated the result pattern was not impacted by any single study. The results of metaregression showed that ethnicity $(P=0.838)$, sample size $(P=0.996)$ and cut-off value $(P=0.959)$ all had no statistically significant influence on the combined effect size for OS.

Four articles evaluated the OS of patients with high density of $\mathrm{CD}^{+}$TILs in ET $[6,21,35]$, and the pooled analysis demonstrated that high density of infiltration of $\mathrm{CD}^{+} \mathrm{T}$ lymphocytes was statistically significant associated with better OS (pooled HR $=0.71 ; 95 \%$ $\mathrm{CI}=0.53-0.97 ; P=0.029$ ) (Figure 2B).

\section{DFS}

Five articles evaluated the DFS of patients with density of $\mathrm{CD}^{+} \mathrm{T}$ lymphocytes in IT [12, 17, 19, 23, 27]. The pooled analysis demonstrated that high density of $\mathrm{CD}^{+}$TILs in IT was statistically significant associated with better DFS (pooled $\mathrm{HR}=0.57 ; 95 \% \mathrm{CI}=0.35-0.94$; $P=0.029$ ) (Figure 2B). However, CD8 ${ }^{+}$TILs in ET was not significantly associated with better DFS $(P=0.950)$

\section{$\mathrm{FOXP3}^{+}$T lymphocyte subset}

A total of 14 articles, including 1,486 patients with gastric cancer, researched the clinical outcome of patients with high density of FOXP3 ${ }^{+}$TILs $[6-8,12,14,16,17$, $21,23,25,31-33,35]$. Stratified by the endpoints, there were 12 of OS and 4 of DFS, respectively.

\section{OS}

Twelve articles focused on the relationship between the density of FOXP3 ${ }^{+}$Treg in IT and OS $[6-8,14,16,17$,
$21,25,31-33,35]$. A random model was used because of a significant heterogeneity $\left(P<0.001, I^{2}=71.6 \%\right)$, and the result demonstrated patients with high infiltration of FOXP $^{+}$Treg had worse OS (pooled HR $=1.57 ; 95 \%$ CI $=1.04-2.37 ; P=0.033$ ) (Figure 2C). Subgroup analysis showed that patients with high density of FOXP3 ${ }^{+}$TILs had worse OS in the groups with Asian patients (pooled $\mathrm{HR}=1.66,95 \% \mathrm{CI}=1.08-2.56 ; P=0.022)$ and large sample size $(\geq 100$; pooled $\mathrm{HR}=1.60,95 \% \mathrm{CI}=1.09$ 2.36; $P=0.016$ ) (Table 3). We further performed a sensitivity analysis which demonstrated the result pattern was not impacted by any single study. The results of metaregression showed that ethnicity $(P=0.860)$, sample size $(P=0.737)$ and cut-off value $(P=0.759)$ all had no statistically significant influence on the combined effect size for OS.

Four articles evaluated the OS of patients with high density of FOXP3 $3^{+}$TILs in ET $[6,14,21]$, and the pooled analysis revealed that high density of infiltration of $\mathrm{FOXP}^{+}$TILs was associated with better OS (pooled $\mathrm{HR}=0.76 ; 95 \% \mathrm{CI}=0.60-0.96 ; P=0.022)($ Figure $2 \mathrm{C}$ ).

\section{DFS}

Four articles researched the DFS of patients with high density of FOXP3 $3^{+}$TILs [12, 16, 17, 23]. Subgroup analysis demonstrated that FOXP3 $3^{+}$TILs was not related to DFS in IT or ET ( $P=0.756, P=0.500$, respectively) (Figure 2C).

\section{$\mathrm{CD3}^{+} \mathrm{T}$ lymphocyte subset}

Seven articles researched clinical outcome of patients with high density of CD $3^{+}$TILs $[5,6,11,16,17$, $21,29]$. Subgroup analysis demonstrated that patients with high $\mathrm{CD}^{+} \mathrm{T}$ cells infiltration in IT had better OS (pooled $\mathrm{HR}=0.52 ; 95 \% \mathrm{CI}=0.43-0.63 ; P<0.001)$ (Figure 2D). In other subgroups, there was no statistical significance (Table 2).

\section{$\mathrm{CD4}^{+} \mathrm{T}$ lymphocyte subset}

Four articles researched clinical outcome of patients with high $\mathrm{CD}^{+} \mathrm{T}$ cells infiltration $[17,20,21,35]$. 
However, subgroup analysis demonstrated that $\mathrm{CD}^{+} \mathrm{T}$ cells infiltration in IT/ET was not significantly associated with survival outcomes (Table 2).

\section{$\mathrm{CD5}^{+} \mathrm{NK}$ cell subset}

Four articles researched the clinical outcome of patients with high $\mathrm{CD}^{2} 7^{+} \mathrm{NK}$ cells infiltration [21, 29, $30,34]$. We found that $\mathrm{CD}^{2} 7^{+} \mathrm{NK}$ cells infiltration in IT was associated with better OS (pooled HR $=0.89 ; 95 \%$ $\mathrm{CI}=0.85-0.94 ; P<0.001)$. However, CD57 $7^{+} \mathrm{NK}$ cells infiltration in ET was not significantly associated with the survival outcome (Table 2).

\section{Other subsets}

There were 3,2, 2 and 2 articles investigated $\mathrm{CD}_{20}{ }^{+}, \mathrm{CD}_{45 \mathrm{RO}^{+}}$, Granzyme $\mathrm{B}^{+}$and T-bet ${ }^{+}$TILs in patients with gastric cancer, respectively $[5,6,12,17,19$, $22,24]$. Subgroup analysis suggested that patients with high density of CD20 $0^{+}$TILs in IT had better DFS (pooled $\mathrm{HR}=0.54 ; 95 \% \mathrm{CI}=0.34-0.86 ; P=0.010)$; patients with high density of CD45RO $\mathrm{RILs}^{+}$in IT had better OS (pooled HR $=0.56 ; 95 \% \mathrm{CI}=0.37-0.84 ; P=0.005$ ), and patients with high density of Granzyme $\mathrm{B}^{+}$TILs in ET had better $\mathrm{OS}(\mathrm{HR}=0.35 ; 95 \% \mathrm{CI}=0.12-0.99 ; P=0.050)$. Moreover, patients with high density of T-bet ${ }^{+}$TILs in IT had better OS $(\mathrm{HR}=0.55 ; 95 \% \mathrm{CI}=0.30-0.99 ; P=$ 0.047 ) and DFS (pooled HR $=0.54 ; 95 \% \mathrm{CI}=0.34-0.87$; $P=0.012$ ) (Table 2).

\section{Publication bias}

We only evaluated the publication bias of subgroups that contained over 10 studies. First, we use the funnel plot to detect the publication bias. The funnel plots of the $\mathrm{CD}^{+}$and $\mathrm{FOXP}^{+}$TILs in IT were substantially symmetric (Figure 3). Then, we used Begg's and Egger's tests to evaluated the publication bias. The $P$ values were all greater than 0.05 . Therefore, our meta-analysis has no publication bias.

\section{DISCUSSION}

The prognostic value of TILs in gastric cancer was quantitatively evaluated in this meta-analysis. Considering the bidirectional role of TILs in tumor-associated immune responses, it is necessary to assess the prognostic role of different TIL subsets. Therefore, we conduct subgroup analyses based on subset of TILs.
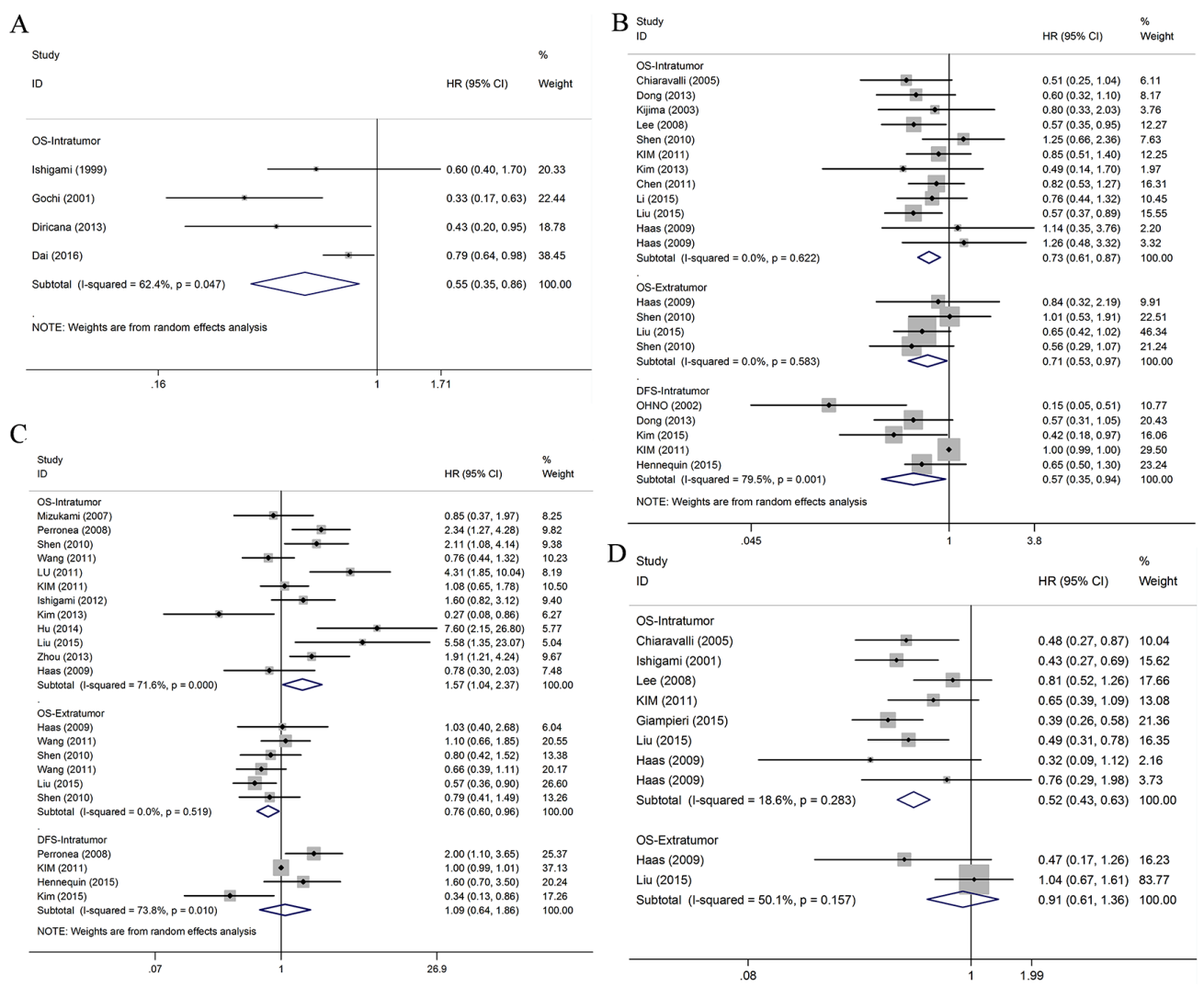

Figure 2: Forest plots of studies evaluating hazard ratios of high level of TILs subsets in gastric cancer by the distribution. (A) Forest plot for the prognostic effect of general TILs. (B) Forest plot for the prognostic effect of CD8 ${ }^{+} \mathrm{T}$ cells. (C) Forest plot for the prognostic effect of FOXP3 ${ }^{+} \mathrm{T}$ cells. (D) Forest plot for the prognostic effect of $\mathrm{CD} 3^{+} \mathrm{T}$ cells. 
Table 3: Pooled hazard ratios for OS according to subgroup analyses

\begin{tabular}{|c|c|c|c|c|c|c|}
\hline \multirow{2}{*}{$\begin{array}{l}\text { OS-Intratumor } \\
\text { subgroup }\end{array}$} & \multirow[t]{2}{*}{ Study number } & \multirow[t]{2}{*}{ Case number } & \multirow[t]{2}{*}{ HR (95\%CI)-model } & \multirow[t]{2}{*}{$P$ value } & \multicolumn{2}{|c|}{ Heterogenety } \\
\hline & & & & & $I^{2}(\%)$ & $P$ \\
\hline \multicolumn{7}{|l|}{$\mathrm{CD} 8^{+}$} \\
\hline \multicolumn{7}{|l|}{ Ethnicity } \\
\hline Asian & 9 & 1348 & $0.72(0.60-0.87)$ - fixed & 0.001 & 0 & 0.619 \\
\hline Caucasion & 3 & 175 & $0.77(0.46-1.29)$ - fixed & 0.318 & 25.9 & 0.259 \\
\hline \multicolumn{7}{|l|}{ Sample size } \\
\hline$\geq 100$ & 7 & 1183 & $0.74(0.48-1.12)$ - fixed & 0.001 & 0 & 0.445 \\
\hline$<100$ & 5 & 340 & $0.73(0.60-0.88)$ - fixed & 0.155 & 0 & 0.528 \\
\hline \multicolumn{7}{|l|}{ Cut-off value } \\
\hline Median & 8 & 1133 & $0.73(0.60-0.89)$ - fixed & 0.002 & 0 & 0.504 \\
\hline Others & 4 & 390 & $0.74(0.50-1.08)$ - fixed & 0.114 & 0 & 0.444 \\
\hline \multicolumn{7}{|l|}{$\mathrm{FOXP}^{+}$} \\
\hline \multicolumn{7}{|l|}{ Ethnicity } \\
\hline Asian & 11 & 1265 & $1.66(1.08-2.56)$ - random & 0.022 & 73.0 & $<0.001$ \\
\hline Caucasion & 2 & 104 & $0.70(0.33-1.48)-$ fixed & 0.350 & 0 & 0.709 \\
\hline \multicolumn{7}{|l|}{ Sample size } \\
\hline$\geq 100$ & 7 & 970 & $1.60(1.09-2.36)$ - random & 0.016 & 80.8 & $<0.001$ \\
\hline$<100$ & 6 & 399 & $1.23(0.47-3.19)$ - random & 0.617 & 58.5 & 0.025 \\
\hline \multicolumn{7}{|l|}{ Cut-off value } \\
\hline Median & 9 & 991 & $1.66(0.96-2.88)$-random & 0.072 & 78.0 & $<0.001$ \\
\hline Others & 4 & 378 & $1.37(0.93-2.03)-$ fixed & 0.115 & 33.0 & 0.214 \\
\hline
\end{tabular}

OS: overall survival; HR: hazard ratio; CI: confidence interval.

Each subset of TILs plays its own roles in the development of gastric cancer, which contribute to their prognostic roles in gastric cancer. CD8, FOXP3, CD3, CD4, CD45RO, Granzyme B and T-bet are mainly located in the surface of T lymphocytes. Some of them are associated with favorable OS and/or DFS. CD8 and Granzyme B are surface antigens of cytotoxic T lymphocytes (CTLs) that are the main effective cells in the anti-tumor immune response [21]. This is in agreement with the results of our study in which these two subsets were associated with better OS and/or DFS. CD3 is a common surface antigen of $\mathrm{T}$ cells, and Arigami et al.
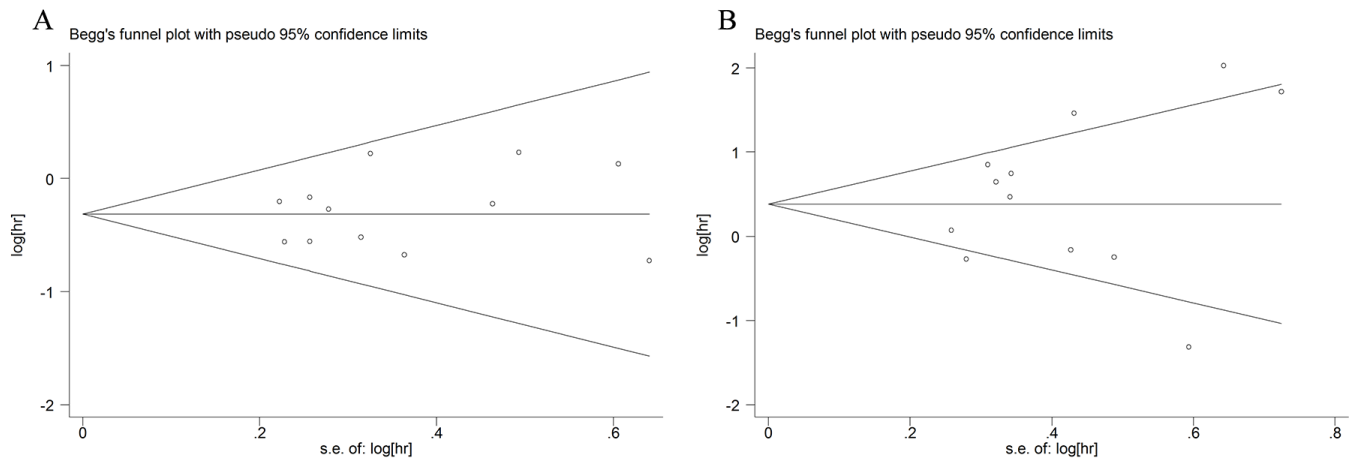

Figure 3: Funnel plots of $\mathrm{CD8}^{+} \mathrm{T}$ cells (A) and $\mathrm{FOXP3}^{+}$Tregs (B) infiltration in tumor nest. 
reported the density of $\mathrm{CD}^{+}{ }^{+}$TILs decreased during tumor progression [36]. It is noteworthy that the prognostic effect of $\mathrm{CD}^{+}$TILs in IT appeared most significant in our study. CD45RO is the most specific surface antigen of memory $\mathrm{T}$ cells, and this subset could prevent peritoneal dissemination of gastric cancer by inhibiting tumor growth and invasion [37]. T-bet is the most specific marker for T helper type 1 (Th1) cells, but besides Th1 cells, CD8 ${ }^{+}$ $\mathrm{CD}^{+}$and $\mathrm{CD}^{2} 6^{+}$lymphocytes also express T-bet [24]. And for $\mathrm{CD}^{+} \mathrm{CD}^{+}$and $\mathrm{CD} 56^{+}$lymphocytes, T-bet is a T-box transcription factor which is crucial for the their differentiation and functions $[38,39]$.

Furthermore, other surface antigens located in $\mathrm{T}$ lymphocytes showed different prognostic roles. $\mathrm{CD}^{+}$lymphocytes include a group of heterogeneous $\mathrm{T}$ lymphocytes, which can secret diverse cytokines, and IL-17 is one of the most representative cytokines. Studies showed that IL-17 could promote tumor angiogenesis, proliferation, migration and invasion [40, 41]. On the contrary, many studies also confirmed IL-17 has anti-tumor effects. Bencherit et al. reported IL-17 could increase the infiltration and cytotoxicity of CTLs [42]. Antonysamy et al. found IL17 could also increase the rate of mature and function of dendritic cells (DCs) [43]. Therefore, the roles of CD4 $4^{+}$TILs are very complicated [44], and in our study, the prognostic value of $\mathrm{CD}^{+}$TILs shows no significance. FOXP3 is the most specific marker on regulatory $\mathrm{T}$ cells (Tregs) that are generally considered to be immunosuppressive and block of effective antitumor immunity, therefore are associated with poor outcome in several kinds of tumors $[45,46]$. But in our study, $\mathrm{FOXP}^{+}$TILs played bidirectional prognostic roles including positive effect in IT and negative effect in ET. That may be because FOXP3 ${ }^{+}$TILs in different anatomical locations may have opposite functions and influences between each other [21].

B cells and NK cells also play important roles in tumor-associated immune responses. CD20 generally exists in the surface of B cells. CD20 $0^{+}$B cells not only contribute to cellular immunity by providing costimulatory signals to $\mathrm{T}$ cells and/or serving as antigen-presenting cells, but also to humoral immunity by producing antibody $[47,48]$. CD57 is a marker of NK cells which could attack tumor cells directly, and the recruitment of NK cells could exhibit strong antitumor activity and generate a better prognosis in gastric cancer $[49,50]$. The functions of these two subsets were consistent with our results.

In addition to prognostic biomarker for gastric cancer, we observed that TILs are potential targets for immunotherapy. Immunotherapy has long been regarded as a powerful anti-tumor treatment which is less toxic and tumor-specific [51]. This treatment contains adoptive cell therapy, monoclonal antibody-based treatment and cancer vaccines. CD8 ${ }^{+}$TILs have crucial targets in these courses. By blocking the interaction of $\mathrm{CD} 8^{+} \mathrm{T}$ cell-related receptors (CTLA-4 and PD-1) and ligands (PD-L2 and PD-L1), anti-tumor immunity is enhanced in patients with advanced solid tumor, including gastric cancer [52]. Champiat et al. also confirmed that augmentation of the local immune response might be a promising target for new immunotherapy [53]. According to our study, the accumulation of $\mathrm{CD} 8^{+}, \mathrm{CD}^{+}, \mathrm{CD} 57^{+}$TILs and depletion of $\mathrm{FOXP}^{+}$TILs were all favorable prognostic factors in gastric cancer. Based on these studies, we propounded $\mathrm{CD}^{+}, \mathrm{CD} 7^{+}$and $\mathrm{FOXP}^{+}$TILs could also serve as targets in immunotherapy like CD $8^{+}$TILs. However, we still need more prospective studies to verify the feasibility of other subsets in future gastric cancer immunotherapy.

To our knowledge, this is the first meta-analysis of evaluating the prognostic role of TILs in gastric cancer. The results from our study should be interpreted with caution for following reasons. First, some studies used different cut-off values that could reduce the practicability of TILs in the process of estimating prognosis. Second, when several HRs were not directly provided in the original studies, we obtained them by calculating the data extracted from the survival curves. Thus, small statistical errors were inevitable. Third, there are still some studies that only used univariate analysis, although univariate analysis may overestimate effect sizes compared to multivariate analysis under common settings. Finally, there are few investigations of some subsets such as $\mathrm{CD}^{2} \mathrm{RO}^{+}$, Granzyme $\mathrm{B}^{+}$and T-bet ${ }^{+}$TILs. This could result in relatively insufficient data in the subgroup analysis.

In conclusion, our meta-analysis provides strong evidence that TILs might serve as a robust marker for predicting the outcome of patients with gastric cancer. Especially, high density of FOXP3 ${ }^{+}$TILs in the ET was a negative prognostic factor, which was opposite to previous results $[6,54]$. We still need more randomized controlled trials to further confirm the results of this meta-analysis.

\section{MATERIALS AND METHODS}

We conducted this meta-analysis according to the Observational Studies in Epidemiology (MOOSE) guidelines [56] and the Systematic Reviews and MetaAnalyses (PRISMA) guidelines [55].

\section{Search strategy}

We searched the literatures published prior to November 2016 through PubMed, Embase and the Cochrane. Keywords used in the search process were "TILs OR tumor-infiltrating lymphocyte OR intratumoral lymphocyte OR tumor infiltrating lymphocyte OR intratumoral lymphocyte OR intratumoral lymphocyte" (all fields) AND "stomach OR gastric" (all fields) AND "tumour OR tumor OR cancer OR neoplasm OR carcinoma" (all fields) AND "prognostic OR prognosis OR outcome OR survival" (all fields). We browsed not only the title and abstract but also the full text of identified 
articles. The availability evaluation and database search were conducted independently by two reviewers. The third reviewer resolved the disagreement from two reviewers.

\section{Inclusion and exclusion criteria}

Only the literatures meeting the following criteria were eligible for inclusion: (1) studies researching the prognostic effect of TILs or associated TIL subsets in gastric cancer; (2) the expression of TILs or associated TIL subsets in IT or ET of patients with gastric cancer; (3) HR and 95\% confidence intervals (CI) could be extracted; (4) the sample size of studies was greater than 50. Several literatures were excluded according to the following criteria: (1) studies with small sample size (< 50 ) were excluded to avoid the publication bias from too small sample size; (2) reviews, letters, case reports, animal trials and conference abstracts were excluded; (3) only the complete or most recent study was enrolled if one patient cohort were researched by multiple studies.

\section{Data extraction}

The author information, publication year, TIL subsets and distribution site, origin of population, tumor stage, cut-off values, sample size, follow-up, detected methods, HRs and 95\% CIs were collected by two researchers. OS and DFS (where possible) were chosen as the indexes of this meta-analysis. Recurrence-free survival (RFS) was used as a substitute if DFS was lacking because RFS is similar to DFS. Compared with univariate analysis, the result from multivariate analysis was preferred because it had improved precision after accounting for confounding factors.

\section{Statistical analysis}

The prognostic effect of different levels of TILs in gastric cancer was evaluated by HRs and 95\% CIs. If the HRs and 95\% CIs were reported in the study, we extracted them directly. Otherwise, we obtained them by calculating the data extracted from Kaplan-Meier survival curves using Engauge Digitizer version 4.1 [57, 58]. The $I^{2}$ statistic and Chi-square test $(P$ value) were used to assess the statistical heterogeneity $[59,60]$. Heterogeneity was suggested when $I^{2}$ was below $50 \%$ and/or $P$ value was greater than 0.05 . The source of heterogeneity was explored primarily through meta-regression and subgroup analysis. Funnel plot, Egger's and Begg's tests were performed to evaluate the publication bias [61]. All analyses were performed using STATA version 12.0 (Stata Corporation, College Station, TX, USA).

\section{ACKNOWLEDGMENTS}

This research project was supported by grants from the National Key Technology R\&D Program
(2015BAI12B12), the National Natural Science Foundation of China (No. 31570877 and 31570908), Jiangsu Engineering Research Center for Tumor Immunotherapy (BM2014404), Jiangsu Key Laboratory of Medical Science and Laboratory Medicine (JSKLM-2014-003), the Key R\&D Project of Science and Technology Department of Jiangsu Province (BE2015633 and BE2016660), Changzhou Science and Technology Project (Applied Based Research, No. CJ20160021) and the Postgraduate Education Innovation Project of Jiangsu Province (ZY32003216).

\section{CONFLICTS OF INTEREST}

None.

\section{REFERENCES}

1. Fock KM. Review article: the epidemiology and prevention of gastric cancer. Aliment Pharmacol Ther. 2014; 40:250-260.

2. Chen W, Zheng R, Baade PD, Zhang S, Zeng H, Bray F, Jemal A, Yu XQ, He J. Cancer statistics in China, 2015. CA Cancer J Clin. 2016; 66:115-132.

3. Balch CM, Riley LB, Bae YJ, Salmeron MA, Platsoucas $\mathrm{CD}$, von Eschenbach A, Itoh K. Patterns of human tumorinfiltrating lymphocytes in 120 human cancers. Arch Surg. 1990; 125:200-205.

4. Schreiber RD, Old LJ, Smyth MJ. Cancer immunoediting: integrating immunity's roles in cancer suppression and promotion. Science. 2011; 331:1565-1570.

5. Lee HE, Chae SW, Lee YJ, Kim MA, Lee HS, Lee BL, Kim WH. Prognostic implications of type and density of tumour-infiltrating lymphocytes in gastric cancer. $\mathrm{Br} \mathrm{J}$ Cancer. 2008; 99:1704-1711.

6. Haas M, Dimmler A, Hohenberger W, Grabenbauer GG, Niedobitek G, Distel LV. Stromal regulatory T-cells are associated with a favourable prognosis in gastric cancer of the cardia. BMC Gastroenterol. 2009; 9:65.

7. Zhou S, Shen Z, Wang Y, Ma H, Xu S, Qin J, Chen L, Tao $\mathrm{H}$, Zhen Z, Chen G, Zhang Z, Li R, Xiao H, et al. CCR7 expression and intratumoral FOXP3 + regulatory $\mathrm{T}$ cells are correlated with overall survival and lymph node metastasis in gastric cancer. PLoS one. 2013; 8:e74430.

8. Kim KJ, Lee KS, Cho HJ, Kim YH, Yang HK, Kim WH, Kang GH. Prognostic implications of tumor-infiltrating FoxP3+ regulatory $\mathrm{T}$ cells and $\mathrm{CD} 8+$ cytotoxic $\mathrm{T}$ cells in microsatellite-unstable gastric cancers. Hum Pathol. 2014; 45:285-293.

9. Gochi A, Orita K, Fuchimoto S, Tanaka N, Ogawa N. The prognostic advantage of preoperative intratumoral injection of OK-432 for gastric cancer patients. Br J Cancer. 2001; 84:443-451.

10. Dirican A, Ekinci N, Avci A, Akyol M, Alacacioglu A, Kucukzeybek Y, Somali I, Erten C, Demir L, Can 
A, Bayoglu IV, Koyuncu B, Ulger E, Tarhan MO. The effects of hematological parameters and tumor-infiltrating lymphocytes on prognosis in patients with gastric cancer. Cancer Biomark. 2013; 13:11-20.

11. Chiaravalli AM, Feltri M, Bertolini V, Bagnoli E, Furlan D, Cerutti R, Novario R, Capella C. Intratumour T cells, their activation status and survival in gastric carcinomas characterised for microsatellite instability and Epstein-Barr virus infection. Virchows Arch. 2006; 448:344-353.

12. Hennequin A, Derangere V, Boidot R, Apetoh L, Vincent J, Orry D, Fraisse J, Causeret S, Martin F, Arnould L, Beltjens F, Ghiringhelli F, Ladoire S. Tumor infiltration by Tbet + effector T cells and CD20+ B cells is associated with survival in gastric cancer patients. Oncoimmunology. 2016; 5:e1054598.

13. Kang BW, Seo AN, Yoon S, Bae HI, Jeon SW, Kwon OK, Chung HY, Yu W, Kang H, Kim JG. Prognostic value of tumor-infiltrating lymphocytes in Epstein-Barr virusassociated gastric cancer. Ann Oncol. 2016; 27:494-501.

14. Wang B, Xu D, Yu X, Ding T, Rao H, Zhan Y, Zheng L, Li L. Association of intra-tumoral infiltrating macrophages and regulatory $\mathrm{T}$ cells is an independent prognostic factor in gastric cancer after radical resection. Ann Surg Oncol. 2011; 18:2585-2593.

15. Dai C, Geng R, Wang C, Wong A, Qing M, Hu J, Sun Y, Lo AW, Li J. Concordance of immune checkpoints within tumor immune contexture and their prognostic significance in gastric cancer. Mol Oncol. 2016; 10:1551-1558.

16. Perrone G, Ruffini PA, Catalano V, Spino C, Santini D, Muretto P, Spoto C, Zingaretti C, Sisti V, Alessandroni P, Giordani P, Cicetti A, D'Emidio S, et al. Intratumoural FOXP3-positive regulatory $\mathrm{T}$ cells are associated with adverse prognosis in radically resected gastric cancer. Eur $\mathrm{J}$ Cancer. 2008; 44:1875-1882.

17. Kim HI, Kim H, Cho HW, Kim SY, Song KJ, Hyung WJ, Park CG, Kim CB. The ratio of intra-tumoral regulatory $\mathrm{T}$ cells (Foxp3+)/helper T cells (CD4+) is a prognostic factor and associated with recurrence pattern in gastric cardia cancer. J Surg Oncol. 2011; 104:728-733.

18. Chen JG, Xia JC, Liang XT, Pan K, Wang W, Lv L, Zhao JJ, Wang QJ, Li YQ, Chen SP, He J, Huang LX, Ke ML, et al. Intratumoral expression of IL-17 and its prognostic role in gastric adenocarcinoma patients. Int J Biol Sci. 2011; 7:53-60.

19. Dong J, Li J, Liu SM, Feng XY, Chen S, Chen YB, Zhang $\mathrm{XS}$. CD33(+)/p-STAT1(+) double-positive cell as a prognostic factor for stage IIIa gastric cancer. Med Oncol. 2013; 30:442.

20. Li K, Zhu Z, Luo J, Fang J, Zhou H, Hu M, Maskey N, Yang G. Impact of chemokine receptor CXCR3 on tumorinfiltrating lymphocyte recruitment associated with favorable prognosis in advanced gastric cancer. Int J Clin Exp Pathol. 2015; 8:14725-14732.
21. Liu K, Yang K, Wu B, Chen H, Chen X, Chen X, Jiang L, Ye F, He D, Lu Z, Xue L, Zhang W, Li Q, et al. Tumorinfiltrating immune cells are associated with prognosis of gastric cancer. Medicine (Baltimore). 2015; 94:e1631.

22. Wakatsuki K, Sho M, Yamato I, Takayama T, Matsumoto S, Tanaka T, Migita K, Ito M, Hotta K, Nakajima Y. Clinical impact of tumor-infiltrating $\mathrm{CD} 45 \mathrm{RO}(+)$ memory $\mathrm{T}$ cells on human gastric cancer. Oncol Rep. 2013; 29:1756-1762.

23. Kim KJ, Wen XY, Yang HK, Kim WH, Kang GH. Prognostic implication of M2 macrophages are determined by the proportional balance of tumor associated macrophages and tumor infiltrating lymphocytes in microsatellite-unstable gastric carcinoma. PLoS One. 2015; 10:e0144192.

24. Chen LJ, Zheng X, Shen YP, Zhu YB, Li Q, Chen J, Xia R, Zhou SM, Wu CP, Zhang XG, Lu BF, Jiang JT. Higher numbers of T-bet(+) intratumoral lymphoid cells correlate with better survival in gastric cancer. Cancer Immunol Immunother. 2013; 62:553-561.

25. Hu M, Li K, Maskey N, Xu Z, Peng C, Wang B, Li Y, Yang G. Decreased intratumoral Foxp3 Tregs and increased dendritic cell density by neoadjuvant chemotherapy associated with favorable prognosis in advanced gastric cancer. Int J Clin Exp Pathol. 2014; 7:4685-4694.

26. Giampieri R, Maccaroni E, Mandolesi A, Del Prete M, Andrikou K, Faloppi L, Bittoni A, Bianconi M, Scarpelli M, Bracci R, Scartozzi M, Cascinu S. Mismatch repair deficiency may affect clinical outcome through immune response activation in metastatic gastric cancer patients receiving first-line chemotherapy. Gastric Cancer. 2016; 20:156-163.

27. Ohno S, Tachibana M, Fujii T, Ueda S, Kubota H, Nagasue $\mathrm{N}$. Role of stromal collagen in immunomodulation and prognosis of advanced gastric carcinoma. Int $\mathrm{J}$ Cancer. 2002; 97:770-774.

28. Ishigami S, Natsugoe S, Tokuda K, Nakajo A, Higashi H, Iwashige H, Aridome K, Hokita S, Aikou T. CD3-zetachain expression of intratumoral lymphocytes is closely related to survival in gastric carcinoma patients. Cancer. 2002; 94:1437-1442.

29. Ishigami S, Natsugoe S, Tokuda K, Nakajo A, Che X, Iwashige H, Aridome K, Hokita S, Aikou T. Prognostic value of intratumoral natural killer cells in gastric carcinoma. Cancer. 2000; 88:577-583.

30. Ishigami S, Natsugoe S, Tokuda K, Nakajo A, Xiangming C, Iwashige H, Aridome K, Hokita S, Aikou T. Clinical impact of intratumoral natural killer cell and dendritic cell infiltration in gastric cancer. Cancer Lett. 2000; 159:103-108.

31. Ishigami $\mathrm{S}$, Arigami $\mathrm{T}$, Uenosono $\mathrm{Y}$, Matsumoto $\mathrm{M}$, Okumura H, Uchikado Y, Kita Y, Nishizono Y, Maemura K, Kijima Y, Nakajo A, Owaki T, Ueno S, et al. Cancerous HLA class I expression and regulatory $\mathrm{T}$ cell infiltration in 
gastric cancer. Cancer Immunol Immunother. : CII. 2012; 61:1663-1669.

32. Lu X, Liu J, Li H, Li W, Wang X, Ma J, Tong Q, Wu K, Wang G. Conversion of intratumoral regulatory $\mathrm{T}$ cells by human gastric cancer cells is dependent on transforming growth factor-beta1. J Surg Oncol. 2011; 104:571-577.

33. Mizukami Y, Kono K, Kawaguchi Y, Akaike H, Kamimura K, Sugai H, Fujii H. Localisation pattern of Foxp3+ regulatory $\mathrm{T}$ cells is associated with clinical behaviour in gastric cancer. Br J Cancer. 2008; 98:148-153.

34. Kijima Y, Ishigami S, Hokita S, Koriyama C, Akiba S, Eizuru Y, Aikou T. The comparison of the prognosis between Epstein-Barr virus (EBV)-positive gastric carcinomas and EBV-negative ones. Cancer Lett. 2003; 200:33-40.

35. Shen Z, Zhou S, Wang Y, Li RL, Zhong C, Liang C, Sun Y. Higher intratumoral infiltrated Foxp3+ Treg numbers and Foxp3+/CD8+ ratio are associated with adverse prognosis in resectable gastric cancer. J Cancer Res Clin Oncol. 2010; 136:1585-1595.

36. Arigami T, Uenosono Y, Ishigami S, Matsushita D, Hirahara T, Yanagita S, Okumura H, Uchikado Y, Nakajo A, Kijima Y, Natsugoe S. Decreased density of CD3+ tumorinfiltrating lymphocytes during gastric cancer progression. J Gastroenterol Hepatol. 2014; 29:1435-1441.

37. Michie CA, McLean A, Alcock C, Beverley PC. Lifespan of human lymphocyte subsets defined by CD45 isoforms. Nature. 1992; 360:264-265.

38. Mullen AC, High FA, Hutchins AS, Lee HW, Villarino AV, Livingston DM, Kung AL, Cereb N, Yao TP, Yang SY, Reiner SL. Role of T-bet in commitment of TH1 cells before IL-12-dependent selection. Science. 2001; 292:1907-1910.

39. Glimcher LH. Trawling for treasure: tales of T-bet. Nat Immunol. 2007; 8:448-450.

40. Fossiez F, Djossou O, Chomarat P, Flores-Romo L, AitYahia S, Maat C, Pin JJ, Garrone P, Garcia E, Saeland S, Blanchard D, Gaillard C, Das Mahapatra B, et al. $\mathrm{T}$ cell interleukin-17 induces stromal cells to produce proinflammatory and hematopoietic cytokines. J Exp Med. 1996; 183:2593-2603.

41. Waugh DJ, Wilson C. The interleukin-8 pathway in cancer. Clin Cancer Res. 2008; 14:6735-6741.

42. Benchetrit F, Ciree A, Vives V, Warnier G, Gey A, SautesFridman C, Fossiez F, Haicheur N, Fridman WH, Tartour E. Interleukin-17 inhibits tumor cell growth by means of a T-cell-dependent mechanism. Blood. 2002; 99:2114-2121.

43. Antonysamy MA, Fanslow WC, Fu F, Li W, Qian S, Troutt AB, Thomson AW. Evidence for a role of IL-17 in organ allograft rejection: IL-17 promotes the functional differentiation of dendritic cell progenitors. J Immunol. 1999; 162:577-584.

44. Chang WJ, Du Y, Zhao X, Ma LY, Cao GW. Inflammationrelated factors predicting prognosis of gastric cancer. World J Gastroenterol. 2014; 20:4586-4596.
45. Gao Q, Qiu SJ, Fan J, Zhou J, Wang XY, Xiao YS, Xu Y, Li YW, Tang ZY. Intratumoral balance of regulatory and cytotoxic $\mathrm{T}$ cells is associated with prognosis of hepatocellular carcinoma after resection. J Clin Oncol. 2007; 25:2586-2593.

46. Bates GJ, Fox SB, Han C, Leek RD, Garcia JF, Harris AL, Banham AH. Quantification of regulatory T cells enables the identification of high-risk breast cancer patients and those at risk of late relapse. J Clin Oncol. 2006; 24:5373-5380.

47. Bouaziz JD, Yanaba K, Venturi GM, Wang Y, Tisch RM, Poe JC, Tedder TF. Therapeutic B cell depletion impairs adaptive and autoreactive $\mathrm{CD} 4+\mathrm{T}$ cell activation in mice. Proc Natl Acad Sci U S A. 2007; 104:20878-20883.

48. Crawford A, Macleod M, Schumacher T, Corlett L, Gray D. Primary $\mathrm{T}$ cell expansion and differentiation in vivo requires antigen presentation by B cells. J Immunol. 2006; 176:3498-3506.

49. Mimura K, Kamiya T, Shiraishi K, Kua LF, Shabbir A, So J, Yong WP, Suzuki Y, Yoshimoto Y, Nakano T, Fujii H, Campana D, Kono K. Therapeutic potential of highly cytotoxic natural killer cells for gastric cancer. Int J Cancer. 2014; 135:1390-1398.

50. Hyakudomi M, Matsubara T, Hyakudomi R, Yamamoto T, Kinugasa S, Yamanoi A, Maruyama R, Tanaka T. Increased expression of fractalkine is correlated with a better prognosis and an increased number of both CD8+ T cells and natural killer cells in gastric adenocarcinoma. Ann Surg Oncol. 2008; 15:1775-1782.

51. Rosenberg SA, Dudley ME, Restifo NP. Cancer immunotherapy. N Engl J Med. 2008; 359:1072.

52. Zhang M, Dong Y, Liu H, Wang Y, Zhao S, Xuan Q, Wang Y, Zhang Q. The clinicopathological and prognostic significance of PD-L1 expression in gastric cancer: a metaanalysis of 10 studies with 1,901 patients. Sci Rep. 2016; 6:37933.

53. Champiat S, Ileana E, Giaccone G, Besse B, Mountzios G, Eggermont A, Soria JC. Incorporating immune-checkpoint inhibitors into systemic therapy of NSCLC. J Thorac Oncol. 2014; 9:144-153.

54. Salama P, Phillips M, Grieu F, Morris M, Zeps N, Joseph D, Platell C, Iacopetta B. Tumor-infiltrating FOXP3+ T regulatory cells show strong prognostic significance in colorectal cancer. J Clin Oncol. 2009; 27:186-192.

55. Liberati A, Altman DG, Tetzlaff J, Mulrow C, Gotzsche PC, Ioannidis JP, Clarke M, Devereaux PJ, Kleijnen J, Moher D. The PRISMA statement for reporting systematic reviews and meta-analyses of studies that evaluate health care interventions: explanation and elaboration. J Clin Epidemiol. 2009; 62:e1-e34.

56. Stroup DF, Berlin JA, Morton SC, Olkin I, Williamson GD, Rennie D, Moher D, Becker BJ, Sipe TA, Thacker SB. Meta-analysis of observational studies in epidemiology (MOOSE) group. JAMA. 2000; 283:2008-2012. 
57. Stang A. Critical evaluation of the Newcastle-Ottawa scale for the assessment of the quality of nonrandomized studies in meta-analyses. Eur J Epidemiol. 2010; 25:603-605.

58. Tierney JF, Stewart LA, Ghersi D, Burdett S, Sydes MR. Practical methods for incorporating summary time-to-event data into meta-analysis. Trials. 2007; 8:16.

59. Higgins JP, Thompson SG. Quantifying heterogeneity in a meta-analysis. Stat Med. 2002; 21:1539-1558.
60. Higgins JP, Thompson SG, Deeks JJ, Altman DG. Measuring inconsistency in meta-analyses. BMJ. 2003; 327:557-560.

61. Duval S, Tweedie R. Trim and fill: a simple funnel-plotbased method of testing and adjusting for publication bias in meta-analysis. Biometrics. 2000; 56:455-463. 